\title{
Chapter 1 \\ Innovation for Marginalized Smallholder Farmers and Development: An Overview and Implications for Policy and Research
}

\author{
Franz W. Gatzweiler and Joachim von Braun
}

\begin{abstract}
Smallholders in Asia and Africa are affected by increasingly complex national and global ecological and economic changes. Agricultural innovation and technology shifts are critical among these forces of change and integration with services is increasingly facilitated through innovations in institutions. Here we focus mainly on innovation opportunities for small farmers, with a particular emphasis on marginalized small farm communities. The chapter elaborates on the concept of the 'small farm' and offers a synthesis of the findings of all the chapters in this volume. The contributions have reconfirmed that sustainable intensification among smallholders is not just another optimization problem for ensuring higher productivity with less environmental impact. Rather it is a complex task of creating value through innovations in the institutional, organizational and technological systems of societies.
\end{abstract}

Keywords Marginality $\bullet$ Poverty $\bullet$ Innovations $\bullet$ Policy $\bullet$ Smallholder farmer

\section{Introduction}

The large majority of the world's 570 million small farms are in Asia and Africa, if we define smallness by land size (Lowder et al. 2014), and about $80 \%$ of them actually live in Asia. They are the largest employment category and small business group among the poor. Their businesses use mostly local resources and face local constraints, but at the same time, they are affected by increasingly complex national and global economic changes. These changes are partly inside farming and partly very much outside agriculture, partly domestic and partly international, i.e.:

- returns to labor in small scale farming are increasingly determined outside agriculture through more integrated labor markets; opportunity costs of farm

\footnotetext{
F.W. Gatzweiler $(\bowtie) \cdot$ J. von Braun

Center for Development Research (ZEF), University of Bonn, Bonn, Germany

e-mail: gatzweiler@gmail.com; jvonbraun@uni-bonn.de
} 
labor are rising, as are aspirations of youth in farming families who do not want to feel relatively deprived;

- agricultural innovation and technology shifts are critical among the forces of change; integration with services is increasingly facilitated through innovations in institutions;

- the market value of smallholder land is rising because of agricultural price changes and the increasing influence of non-agricultural demand for land use, as well as expected value changes in other capital asset classes;

- international dynamics result from changing price levels and volatility, and trade policies defining competitiveness; consumption shifts are among the fundamental drivers;

- domestic policies, especially the scale and pattern of investments in public goods, such as infrastructure, innovation systems, and social policy, change the socio-economic framework of small scale farming.

This volume and the overview chapter focuses mainly on innovation opportunities for small farmers. The other above-mentioned important forces of change are touched upon only as a backdrop. Moreover, we focus in particular on marginalized small farm communities. ${ }^{1}$ Small farmers have shown strong resilience in the context of economic transformation. They are faced with forces of continuing change in coming decades, including far more integrated and quality-focused agricultural value chains and more complex technological and institutional choices for production, processing and marketing. Policies must be designed to facilitate an integral role for small farm households not only as passive absorbers of change, but as important contributors to development.

\section{Defining Small Farms Comprehensively}

Small farms are highly heterogeneous and diverse. Small farmers exhibit specific characteristics and play different (sometimes multifunctional) "roles" in their regions, and these roles differ in significance at different stages of economic development. Most of the literature defines small farms based on the size of their land or livestock holdings (Eastwood et al. 2010), a standard but arbitrary cut-off size being less than 2 ha (World Bank 2003). Land quality and access to resources such as water are also key differentiators of small farms. It is important to capture the institutional and technical characteristics in the definition of small farm. Being small is not only about the land or herd size, but also about varied access to markets and natural resources and the degree of commercialization (von Braun and

\footnotetext{
${ }^{1}$ We define marginality as "an involuntary position and condition of an individual or group at the margins of social, political, economic, ecological, and biophysical systems, that prevent them from access to resources, assets, services, restraining freedom of choice, preventing the development of capabilities, and eventually causing extreme poverty" (von Braun and Gatzweiler 2014).
} 
Table 1.1 Defining small farms: concepts and criteria

\begin{tabular}{l|l|l|l}
\hline Concepts & Measurements & Strengths & Deficiencies \\
\hline $\begin{array}{l}\text { 1. Land } \\
\text { holding } \\
\text { size }\end{array}$ & $\begin{array}{l}\text { Size in hectares } \\
\text { cultivated } \\
\text { Number of } \\
\text { livestock }\end{array}$ & $\begin{array}{l}\text { Simple accounting of } \\
\text { physical characteristics; } \\
\text { Important for agrarian } \\
\text { societies }\end{array}$ & $\begin{array}{l}\text { Lack of economic valuation } \\
\text { of farm enterprise (quality of } \\
\text { land, location to markets, } \\
\text { etc.); ownership issues } \\
\text { neglected }\end{array}$ \\
\hline $\begin{array}{l}\text { Employment } \\
\text { farms }\end{array}$ & $\begin{array}{l}\text { Labor in small } \\
\text { farms }\end{array}$ & $\begin{array}{l}\text { Important for economy- wide } \\
\text { considerations, and for } \\
\text { livelihoods }\end{array}$ & $\begin{array}{l}\text { Returns to labor (especially } \\
\text { marginal returns) undefined; } \\
\text { economics of multiple } \\
\text { job-holdings missing }\end{array}$ \\
\hline $\begin{array}{l}\text { 3. Income } \\
\text { tion and net } \\
\text { returns }\end{array}$ & $\begin{array}{l}\text { Integrates with GDP shares; } \\
\text { identifies growth and innova- } \\
\text { tion performance; a basis for } \\
\text { poverty identification in the } \\
\text { small farm economy }\end{array}$ & $\begin{array}{l}\text { Highly variable; pricing own } \\
\text { consumption of farm } \\
\text { products; externalities not } \\
\text { captured (eco-systems } \\
\text { services) }\end{array}$ \\
\hline $\begin{array}{l}\text { 4. Total eco- } \\
\text { nomic value } \\
\text { (TEV) }\end{array}$ & $\begin{array}{l}\text { Comprehensive } \\
\text { capital stock } \\
\text { (assets) account }\end{array}$ & $\begin{array}{l}\text { Identification of wealth; } \\
\text { credit worthiness; important } \\
\text { for economy- wide consider- } \\
\text { ations beyond GDP }\end{array}$ & $\begin{array}{l}\text { Difficulties to value land } \\
\text { and human capital (skills); } \\
\text { value of inter-farm } \\
\text { collective action (as a form } \\
\text { of social capital) }\end{array}$ \\
\hline $\begin{array}{l}\text { 5. Societal } \\
\text { role }\end{array}$ & $\begin{array}{l}\text { Small-farm } \\
\text { communities; } \\
\text { villages; local } \\
\text { services }\end{array}$ & $\begin{array}{l}\text { Shows collective action } \\
\text { (potentials); governance and } \\
\text { fiscal settings; public goods } \\
\text { investments }\end{array}$ & $\begin{array}{l}\text { Lacks focus on the farm } \\
\text { enterprises }\end{array}$ \\
\hline
\end{tabular}

Source: von Braun and Mirzabaev (2015)

Mirzabaev 2015). Given the important role of small farms in reducing rural poverty, the definition of small farms ideally should be asset- and income-based (ibid.), not solely area-based.

Actually, a whole dashboard of concepts and related measurable criteria should be applied to identify size, relevance and potential of the small farm economy. Table 1.1 lists such a dashboard of five sets of concepts (land size, employment, $\mathrm{TEV}$, income, socio-economics). The literature is rich in studies on all these five concepts and, to some extent, their inter-linkages. A general international statistical basis, however, exists only for the land-based accounting of "small farms", and even that is quite deficient (Lowder et al. 2014). The definition of farm class sizes for which data are collected is often divergent among countries, making their crosscountry comparisons challenging (FAO 2010). Moreover, the discussion of small farms is dominated by crop production, whereas small pastoralists are usually not much taken into consideration, with little attention being paid to small scale horticulturalists and aquaculturalists as well.

Using the area size of a farm alone to identify whether it is small or big may lead to misguided policy actions. For example, 1 ha of irrigated fertile land planted with high value vegetables and fruits and located close to major urban markets could generate much higher total income than, say, 20 ha of rainfed area under subsistence crops in remote areas. The same 1 ha of irrigated land may lead to quite 
divergent incomes depending on whether it is sustainably managed or highly degraded (Nkonya et al. 2011).

\section{Determinants of "Smallness” of Farms}

Smallness of farms is largely endogenous. The fundamental insights of Tschajanov (1923) based on empirical analyses of the relationships between labor use and farm size in Russia around the beginning of the twentieth century emphasized that the small farm (including household plots for home production) should not be viewed as just a short-term transitional phenomenon. It is an economic reality and it depends directly on the household utility function and on the underlying economic conditions in product and labor markets, as well as social system risks. The factors that put small farms at an advantage or disadvantage compared to large farms have been debated by economists for years, and there are long-standing debates on the viability and the role of small farms in economic development (Schultz 1964; von Braun and Kennedy 1994; Hazell et al. 2010). The seminal research of Schultz (1964) on the efficiency of small and poor farmers brought many misleading debates, equating small with inefficient, to an end.

Often, small farms are not considered "viable", but concepts of viability need to be carefully assessed in relation to small farms. Economic viability in family farming means the ability and capacity of a farm to 'make a living', say, over the seasons of a year or over the long run. Given the relevance of multiple job holdings on small farms, defining viability purely on the basis of the farm component of the households' total economy is inappropriate, as farm production, labor and capital allocation are optimized in an integrated, inseparable fashion in most instances (Singh et al. 1986). Furthermore, defining small farm viability from an economywide perspective would need to be based on considerations of TEV and productivity (innovation) potentials. These "people potentials" in the small farm sector, such as entrepreneurship and expanding human capital, may be much more relevant for growth and development, rather than simply being the economics of land connected to the small farm economy.

The concept of returns of scale has been used to probe many of the theories of optimal farm size (Chavas 2001). Empirical studies of this inverse relationship in the 1970s found that, in India, small farms are more technically efficient than large farms (Yotopoulos and Lau 1973; Berry and Cline 1979). Hired labor is the main reason for the lower land productivity of larger farms (Binswanger and Rosenzweig 1986). Family workers are more efficient than hired workers because family members receive a share of the profit and thus pay greater attention to quality of work than hired labor. Family members also require no hiring or search costs, and each family member assumes a share of the risk; however, there are tendencies towards (self-) exploitation of labor in family farming, especially in relation to child labor (ILO 2006) and remuneration of women's work. 
In many cases, the small family farm is the optimum size because scale economies that arise from using inseparable inputs (like machinery) are offset by the scale diseconomies that arise from using hired labor (Hayami 1996). Ultimately, the optimal farm size will be the one under which labor productivity of the agricultural sector approaches that of the non-agricultural sector, given the same quality of labor. Transitions to such a state can take a long time due to institutional rigidities, transformation risks, and policies. A simple calculation highlights this: under an assumption of farm closure rates of $5 \%$ per annum (be it through sales or renting out), it would take 45 years to move from an average of 1-ha farms to an average of 10-ha farms. Europe has only managed that process with half such an exit rate. These small farms will be there for many years to come. Radically accelerated and enforced change in farm size usually entails suffering and is economically inefficient.

Small farms require focused developmental attention for several reasons. Firstly, they play key roles in broader economic transformations. Considering that small farms are home to large shares of populations in developing countries, the successes of economic transformation need to take the economy-wide roles of small farms into account. Secondly, the protection and sustainable use of natural resources by small farms is becoming a critical aspect of their productivity. For example, land degradation is found to affect more than three billion people around the world, the majority of whom are small farmers and pastoralists in developing countries (Le et al. 2014), and has serious economic consequences for them (Nkonya et al. 2011). Thirdly, globalization and changes in markets offer new opportunities and competitive threats for small farms. These opportunities and threats need to be evaluated with a view to enabling small farmers to successfully integrate into new value webs or at least partly exit agriculture in favor of nonfarm activities. Fourthly, small farms play a key role in reducing poverty. Most of the poor in the world reside on small farms (von Braun 2011), so what happens on small farms will be decisive in actions against poverty. And among the population, those most affected by food insecurity are the smallholder farmers, because of income and direct production linkages. Therefore, if these farmers were better off, hunger and the sticky problem of child malnutrition would diminish.

\section{Patterns and Change of Small Farms}

The world currently has about 570 million farms, if we include small household agricultural production (Lowder et al. 2014). Table 1.2 depicts their estimated size distribution. Approximately $85 \%$ of the world's farms are smaller than 2 ha. About half of small farms are in low or lower middle income countries (Lowder et al. 2014). The majority of farms, including small farms, are located in Asia, particularly China and India. It should be stressed that land quality differs widely among these small holdings.

Average farm size is decreasing in Asia and Africa. However, in those countries which are experiencing farm size decreases, the rate of decrease has decelerated, 
Table 1.2 An approximation of world farm size distribution by regions

\begin{tabular}{|c|c|c|c|c|c|c|}
\hline \multirow[b]{2}{*}{ Region } & \multicolumn{6}{|c|}{ Land size classes } \\
\hline & $<1$ ha & $1-10$ ha & $10-50$ ha & $50-100$ ha & $100-500$ ha & $>500$ ha \\
\hline Asia & $78 \%$ & $19 \%$ & $1 \%$ & - & - & - \\
\hline Sub-Saharan Africa & $62 \%$ & $37 \%$ & $1 \%$ & - & - & - \\
\hline $\begin{array}{l}\text { Middle East and North } \\
\text { Africa }\end{array}$ & $60 \%$ & $33 \%$ & $7 \%$ & - & - & - \\
\hline $\begin{array}{l}\text { Latin America and } \\
\text { Caribbean }\end{array}$ & $17 \%$ & $47 \%$ & $23 \%$ & $6 \%$ & - & - \\
\hline Europe & - & $77 \%$ & $15 \%$ & $3 \%$ & $3 \%$ & - \\
\hline $\begin{array}{l}\text { North America and } \\
\text { Australia }\end{array}$ & - & $19 \%$ & $32 \%$ & $16 \%$ & $24 \%$ & $9 \%$ \\
\hline
\end{tabular}

Source: data from Lowder et al. (2014), FAO datasets

Note: Blank cells mean the number of farms under this land size class is less than $0.1 \%$ of the total

whereas some countries, notably China and Vietnam, have begun experiencing a recently increasing trend in their average farm sizes. The share of the active population employed in agriculture is decreasing, albeit at a much slower rate than the share of agriculture in GDP. As a result, even in countries where agriculture plays a minor role in terms of its contribution to GDP, its role in employment is still quite substantial (von Braun and Mirzabaev 2015).

\section{Size and Productivity}

Cross-country comparisons show that average farm size is positively associated with agricultural value added per worker. The comparison of agricultural growth rates with changes in farm size, however, does not show a consistent picture for the Asian countries (Fig. 1.1): The overall trend seems to show that increase in farm size is associated with faster agricultural growth, but this seems heavily influenced by just a few countries (Tajikistan, Uzbekistan, South Korea, Vietnam). The results for SSA countries (Fig. 1.2) show little association between farm size changes and the rates of agricultural growth. Most of the Asian and SSA countries have very small average farm sizes, so passing from, say, $0.4-0.8$ ha may not necessarily instigate any strong qualitative changes that influence agricultural growth rates.

Several studies found small farms to have higher land productivity than bigger farms due to higher incentives and productivity of family labor (Eastwood et al. 2010), especially in Asia where labor is more abundant than land (Hazell et al. 2010). For example, decreasing returns to scale in agricultural production were found in East Java, Indonesia (Llewelyn and Williams 1996), and Pakistan (Heltberg 1998). However, Fan and Chan-Kang (2005) also indicate that, in certain cases, once the varying degrees of soil fertility and land potential (irrigated vs. rainfed) are taken into account, the diseconomies of scale in land productivity between small and large farms may disappear. Moreover, there is plentiful evidence 


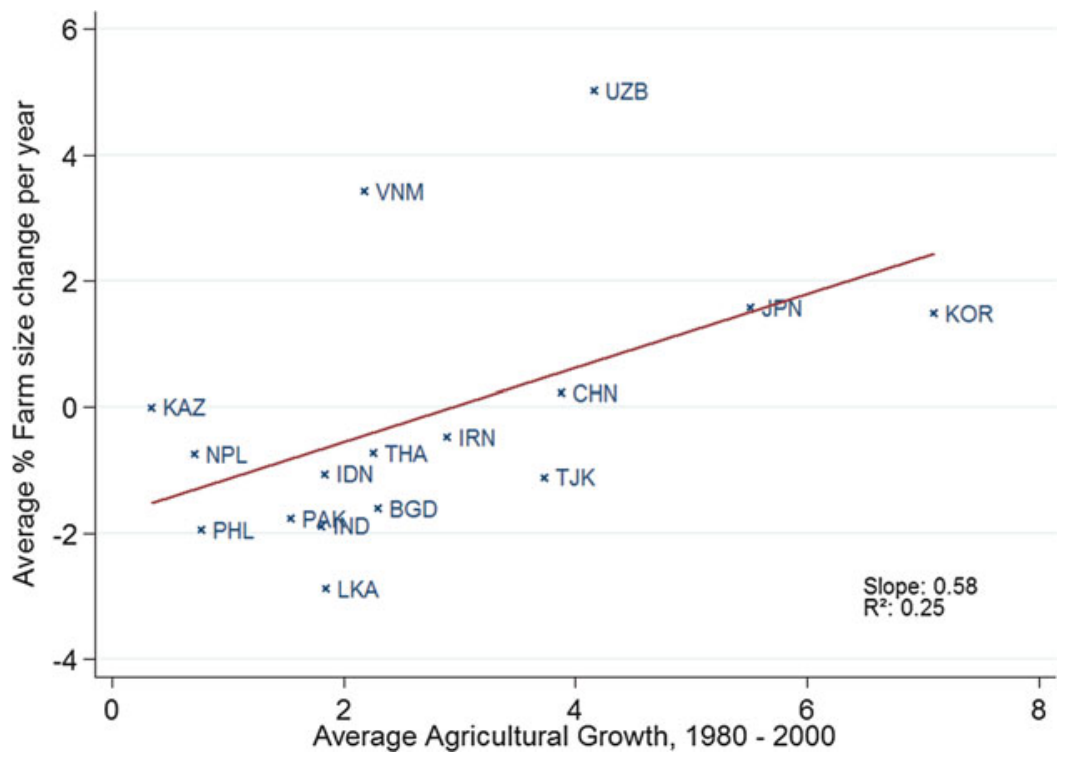

Fig. 1.1 Average annual changes in farm size and average agricultural growth rates in Asia (Sources: von Braunand Mirzabaev (2015), based on word development indicators, World Bank, and Lowder et al. (2014), FAO)

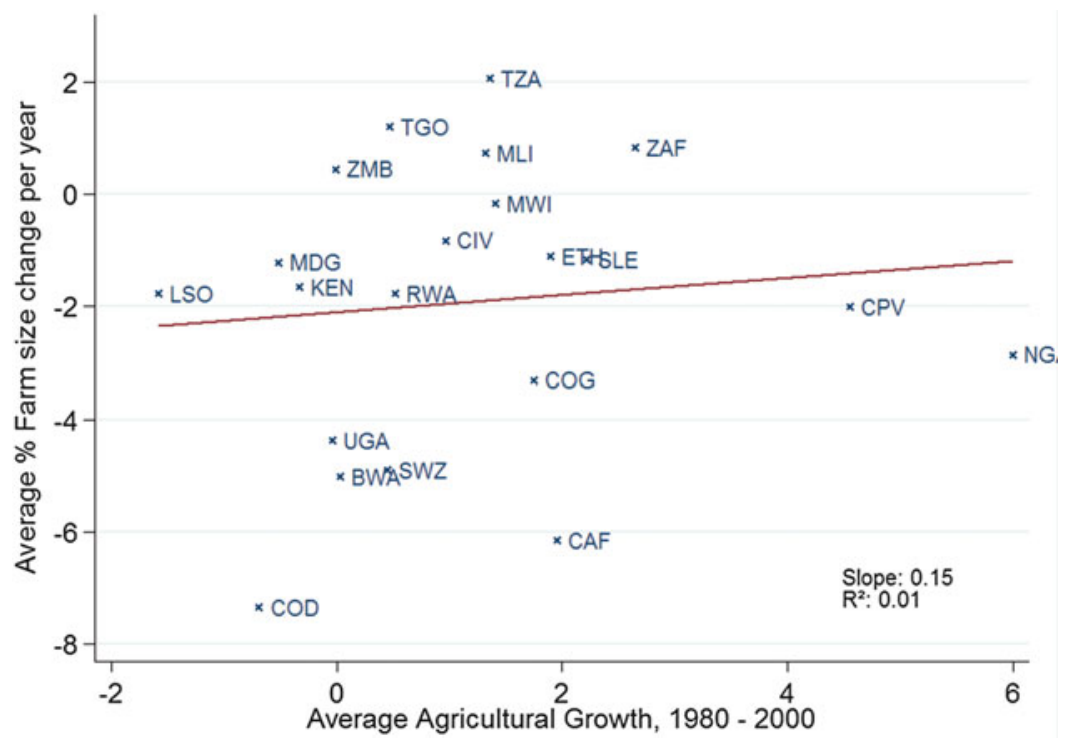

Fig. 1.2 Changes in farm size and average agricultural growth rates in SSA, both in logs (Sources: von Braun and Mirzabaev (2015), based on word development indicators, World Bank, Lowder et al. (2014), FAO) 


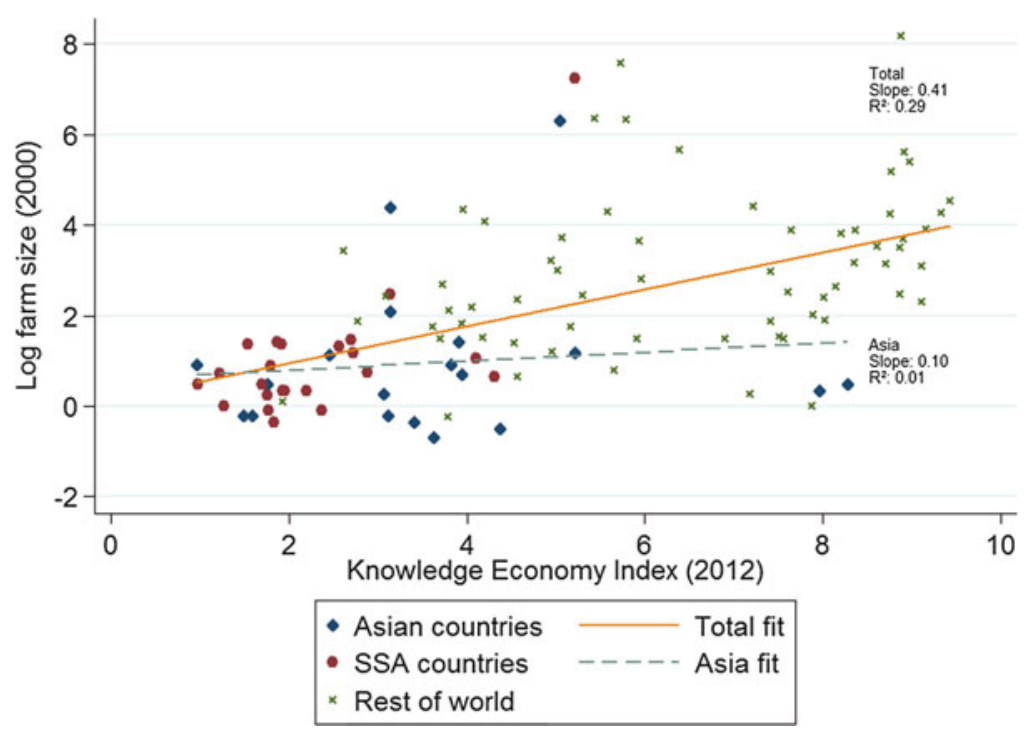

Fig. 1.3 Farm size and knowledge economy (Index, both in logs) (Sources: von Braun and Mirzabaev (2015) based on Lowder et al. (2014), FAO; World Development Bank)

that small farms could be less efficient in terms of labor productivity (ibid.). Wiggins et al. (2010) conclude that the distinct advantages of small farms are present in cases when the main agricultural input is family labor and there is very little use of external inputs, the production being chiefly for home consumption with whatever surpluses exist being sold to small-scale traders. There is no clear-cut answer to the question as to whether small farms perform more productively under what circumstances. Certainly, the performance of small farms is modulated by a variety of accompanying policy, institutional, market and agro-ecological conditions. In fact, the variations in farm size could be explained either by deliberate national policies (Fan and Chan-Kang 2005) or by varied population pressures (Eastwood et al. 2010).

In view of the rising role of innovation (Total factor productivity, TFP) in agricultural growth (Fuglie 2013), we would expect that agriculture grows more and better if accompanied by a strong knowledge society. The comparison of average farm size and the knowledge economy index ${ }^{2}$ shows positive association globally, but less so in emerging economies (Fig. 1.3).

\footnotetext{
${ }^{2}$ The Knowledge Economy Index (KEI) measures a country's ability to generate, adopt and diffuse knowledge. It takes into account whether the environment is conducive for knowledge to be used effectively for economic development.
} 


\section{Persisting Rural Poverty and Untapped Potential}

Deprivation, hunger and malnutrition remain predominantly rural. Globally, a billion people still live in extreme poverty. Progress in reaching the poorest and most marginalized has been slow, and income inequality continue to increase. The depth of poverty has become less severe, however, most improvements have been achieved in China and India. For other developing countries, the number of people living in extreme poverty today is as bad as it was 30 years ago (Olinto et al. 2013). However, even in China and India, growth has been unevenly distributed, and poverty persists in China's interior and in three of India's states in particular. Moreover, income inequality, the difference between average rural and urban incomes, is increasing, as well as inequality in terms of access to land. The majority of farms in low income countries cover less than 2 ha, and in Sub-Saharan Africa, less than 1 ha (von Braun 2005, von Braun and Mirzabaev 2015).

New efforts need to be made to reach out to those persisting in poverty. For that reason, research into agricultural innovation needs to develop ways for improving the lives of the rural marginalized and poor. Our starting point for re-addressing the topic of agricultural innovation is a new perspective on the lives of the rural poor, by recognizing developmental potential along social and ecological dimensions: capabilities of the rural poor and agro-ecological potential. Identifying those dimensions recognizes that rural poverty is a multi-dimensional phenomena. Agro-ecological potential refers to potential provided by the land and its respective ecosystem services. Since the 1970s, agro-ecological zoning has been used for determining agricultural production potential (Beddow et al. 2010, pp. 8-38)

We take a spatial-, people-, and transaction-specific approach to matching institutional and technological innovations with human capacities and agroecological potential. Such an approach recognizes the challenges of adopting technological innovations in complex marginalized social and ecological environments. The conceptual framework we have developed aims to identify suitable strategies and innovations for different segments of marginalized smallholders in agriculture, along a gradient of human capability and agro-ecological potential. Sustainable intensification is thereby achieved through different strategies in specific contexts and can mean increasing crop harvest per area, increasing crop diversity per area and nutrient supply per household member, or increasing income opportunities and household income.

According to Sen (1999), capabilities are realized freedoms for people to do and be what they value. Having capabilities enables people to actually make choices from a set of opportunities, which requires freedom to choose and the availability of options to choose from (which he refers to as functionings). Freedom does not mean "free from any restraint" but rather the possibility to actually choose to be and do. Having fewer choices can sometimes be more enabling (and thereby contribute to wellbeing) than having to make (costly) trade-offs among many choices. The central idea behind the concept of capabilities is to increase freedoms and not only to increase the number of choices. Realized capabilities are "functionings". 


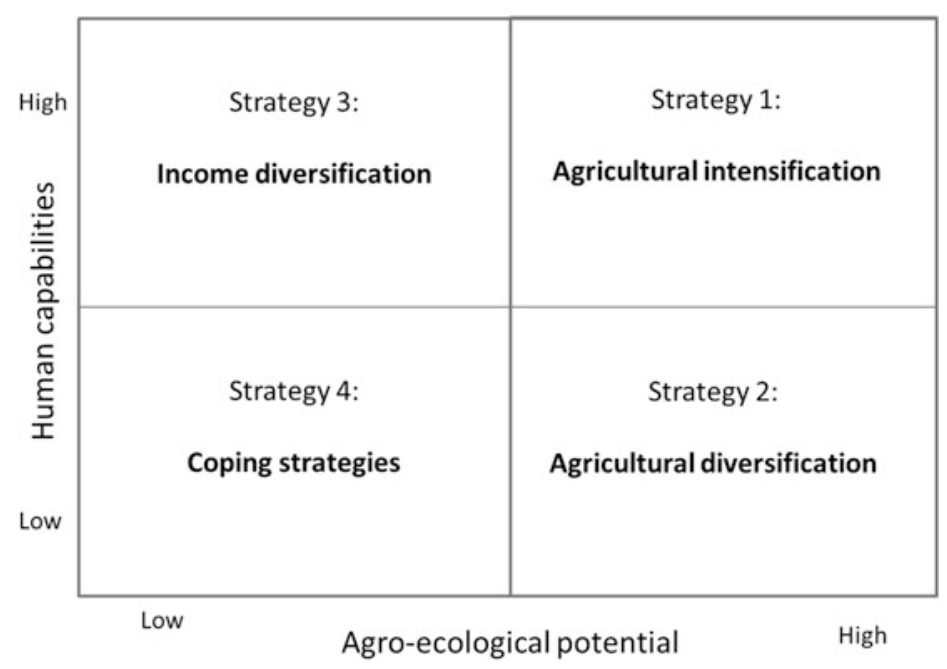

Fig. 1.4 Potential strategies, technological and institutional innovations within the field of tension between human capabilities and agro-ecological potentials

Four broad people-and-land related segments within those two dimensions can be identified (Fig. 1.4): (1) Areas where rural populations have relatively high capabilities and land with relatively high agro-ecological potential (AEP). (2) Areas where the level of human capabilities are relatively high but AEP is low. (3) Areas where human capabilities are relatively low and AEP is high. And (4) where capabilities and AEP are both low.

What our framework essentially shows is that when high capabilities overlap with low agro-ecological potential, the "realized freedoms" cannot be achieved alone from tapping unused agro-ecological potential or closing yield gaps by means of technological innovations in agriculture. Rather, they need to be achieved by alternative income opportunities - either in agriculture related service or business sectors or outside of the agricultural sector.

Within each segment, different types of innovation help the rural poor to improve wellbeing. "Innovation is the process by which inventions are produced - it may involve new ideas, new technologies, or novel applications of existing technologies, new processes or institutions, or more generally, new ways of doing things in a place or by people where they have not been used before" (Juma et al. 2013, p. 2). We refer to institutional and technological innovations as doing things in new ways, on the basis of new sets of rules or organization or by means of technical inventions which are introduced or have been invented by the smallholders themselves.

Innovations for the rural poor include institutional and technological innovations which broaden the set of opportunities for the poor to improve their wellbeing (Conway and Waage 2010). Technological innovations in agriculture can improve wellbeing by increasing efficiency in the production process and reducing labor 
costs. Institutional innovations can improve the wellbeing of the poor, e.g., through improved access to land, better land use rights, or better income opportunities that do not involve working on the land. The two cannot be entirely separated, however, distinguishing between them shows different opportunity sets for the rural poor to improve their wellbeing.

\section{Innovation Strategies for the Rural Poor}

The number of rural poor has persisted, despite successful attempts at various innovation approaches in agriculture, such as the agricultural innovation system (AIS) approach (Leeuwis and Ban 2004; Bergek et al. 2010) or the science-based productivity enhancement approach of the Green Revolution. Many of the remaining rural poor are poor, not only because they are unable to produce more product more efficiently, but because they remain marginalized (von Braun and Gatzweiler 2014). Enhancing agricultural productivity by means of improved seeds, fertilizer and pesticide use, and by reducing post-harvest losses, are definitely among the options for innovation for some rural poor. However, those innovations will not solve the problems of fragmented farm sizes and exploitative relations between landowners and tenant farmers.

Improving the wellbeing of the rural poor will need to be achieved by providing opportunities for increasing capabilities and widening the innovation portfolio by following strategic pathways out of rural poverty. According to our framework (Fig. 1.4), we identified three strategic options and four strategies for each segment of the rural poor. The strategic options are: (1) Intensification, (2) Diversification, and (3) Coping strategies.

The dominant type of productivity to be improved in each segment varies. Innovations which lead to improved land productivity will be favored in segments 1 and 2, where agro-ecological potentials are relatively high. Innovations which lead to improving labor productivity will be favored in segments 1 and 3, where human capabilities are relatively high. In segment 4 , intensified efforts for improving both types of productivity need to be made. This segment is typically the domain of development organizations and needs to be embraced by national development and social safety net programs.

Strategy 1 applies to areas with relatively high human capabilities and relatively high agro-ecological potential. This segment is preferable for Green Revolution type of interventions. Land which is agro-ecologically suitable and located in areas with high population densities also shows high opportunity costs of land and labor. People have income opportunities other than working in agriculture, demand for agricultural products increases and land is becoming scarce. Those developments lead to adopting a strategy of intensification, typical for the Green Revolution in Asia and Latin America (Pingali 2012).

Here, a strategy of sustainable agricultural intensification could involve improved access to production means, e.g., high yielding varieties, fertilizer, 
pesticides, and seeds to enhance productivity through intensification (The Montpellier Panel 2013). In this segment, technological and institutional innovations need to support the aim of increasing yields per area of land.

The optimism for productivity gains in segment 1 , however, needs to be accompanied by a word of caution. Decreasing land/labor ratios alone does not automatically suggest similar opportunities for intensification, especially not in marginalized areas where infrastructure development is not a priority, alternative income opportunities are scarce, and property rights do not favor the majority of the poor and are unlikely to change. In those areas, the rural poor are predominantly wage laborers who engage in multiple income generating activities, and even when agricultural productivity increases as a result of intensification, the majority of the rural poor, who might be tenant farmers, do not benefit from that growth (Singh 2012).

This has been shown by Hirway and Shah (2011), who detected a low elasticity of poverty reduction to growth 1993-2005 for the state of Gujarat, India. Despite growth, the state of Gujarat slipped from rank 6 to 12 in rural poverty, from rank 5 to 9 on the Human Development Index (1996-2006), its health and education index decreased by one rank, and it was among the five states in India, together with Bihar, performing worst on the Global Hunger Index (IFPRI 2009). Also, the Gini coefficient of income for Gujarat was 0.47, indicating extremely unequal income distribution (Shukla 2010).

Strategy 2 applies to areas which show low levels of capabilities and high agroecological potential, i.e., extreme poverty in areas with high agro-ecological potential. In those areas, a strategy of agricultural diversification (possibly including non-staples and animal production) could enable food security. In this segment, innovations need to support the aim of diversifying and increasing agricultural yields per land area.

Marginalized rural populations in segment 3 are characterized by relatively high capabilities and low agro-ecological potential (less favored or highly marginal). Strategies of income diversification are promising and could include measures which facilitate access to agricultural and non-agricultural markets. Examples for measures taken in this segment include access to micro-credit, social protection, and seeds which are stress tolerant and can cope in harsh environments. In this segment, innovations should support the goal of increasing income opportunities per household.

In segment 4 , stallholders have the lowest capabilities and live in areas with low agro-ecological potential, i.e., extreme poverty in harsh environments. Integrated strategies apply which involve access to land, water and public services such as education and health. Examples are integrated rural development approaches or BRAC's program for the ultra-poor in Bangladesh that facilitate readiness for participation in mainstream development initiatives. Innovations in this segment are also people-focused, as in segment 3 , and aim to secure livelihoods by diversifying strategies for coping.

Poor smallholders in Sub-Saharan Africa and South Asia are rather vulnerable to technological changes introduced from outside (Holmes and Jones 2009; Farrington et al. 2007). Even the most promising innovations in agricultural technology, which fit the local ecological environment and promise to close yield gaps, are not 
automatically accompanied by programs which reduce risks, enable smallholders to scale up production levels or secure them the benefits from productivity increases. Tapping agro-ecological potentials by means of agricultural technology innovations will therefore be more sustainable the more the human capabilities of the marginalized smallholders are realized.

\section{Overview: Innovative Intensification and Diversification for and with Marginalized Small Farmers}

This volume is structured according to the major innovation strategies we have identified in our framework. Part I (Chaps. 2, 3, 4 and 5) presents theoretical insights into innovation at multiple scales of society. Foundations are laid for understanding sustainable intensification in agriculture as a complex development towards creating value in multiple domains of society, economy and ecology. Contributions in this part of the volume look into how innovation occurs in multi-layered social organization (polycentricity) and how the human psychology of innovation works. A theoretical model for technological adaptions among marginalized smallholders is presented, as well as impacts and trends in innovations for food security.

Gatzweiler (Chap. 2) explains how institutions can be enabling or inhibiting for the rural poor to escape poverty. He shows how rule changes within multi-layered, nested (polycentric) social order can create value horizontally and vertically, either from inside social systems or externally induced, by reducing transaction costs and enabling connectivity, interactions, exchange, and communication. Technological and institutional innovations can change the rule-change calculus, providing incentives to change the sets of rules which keep smallholders marginalized, and thereby better position them in society to escape poverty. Accordingly, sustainably improving the lives of smallholders in Sub-Saharan Africa and South Asia cannot be achieved by improving productivity through technology innovations alone institutional innovations are required for smallholders to change their marginalized positions in society.

Food and nutrition security among rural smallholders remain in a critical state. Pangaribowo and Gerber (Chap. 3) address the issue by presenting the current situation which, despite overall progress, still gives reason for concern, especially in Sub-Saharan Africa and South Asia. They provide examples of how new platforms and traditional technological innovations (see also Chap. 9) but also institutional innovations enable farmers to collaborate and learn from each other, and thereby can have positive direct or indirect impacts on food and nutrition security.

Little attention has been paid to the states of mind which drive innovation. In Chap. 4, Manasi Kumar and Ashish Bharadwaj look at the psychology behind innovations, identify barriers and processes of innovation diffusion, and explain when internal stimuli for innovation might be more promising as compared to externally inducing innovation as a result of uncertainty perception. They provide 
answers to the questions of how, when and where creativity and innovation occur among the rural poor and why poverty and deprivations can mar capacities that drive novelty seeking behavior. The insights the authors provide into the psychology of innovation illustrate the circumstances under which an innovation is worthwhile and why it is that, as time passes, the motivational and need structures can change for the worse.

In Chap. 5, Iskandar and Gatzweiler develop an optimization model showing that productivity gains among rural smallholders can be achieved, but are conditional on human and natural capital stocks and transaction costs. Corresponding to the conceptual frame proposed by Gatzweiler and von Braun in Chap. 1, they explain why adjustments in rural infrastructure and institutions to reduce transaction costs is a more preferable investment strategy than adjusting agricultural technologies to marginalized production conditions. After defining the optimization problem for rural households under the poverty and survival line, the authors observe the impact of technology adoption and the transaction cost effects on the income generation capacity in specific segments of the rural poor. Their analysis sheds light on the question of why technology adoption is not the preferred strategy for productivity growth under the presence of high transaction costs which are common amongst poor smallholders.

Part II consists of contributions from the Asian and African Regions which present examples of income and production diversification strategies. The authors present studies on the role of large non-governmental organizations, private businesses and governmental organizations for facilitating income and agricultural diversification strategies, show innovative approaches for encouraging smallholders to make use of local innovations, project the potential impacts from innovations in agriculture on gender, and deliberate on the underused potential of synergy effects in interwoven value chains, so-called value webs, in the bioeconomies of Subsahan Africa and South Asia.

In Chap. 6, Mazid et al. present the BRAC approach to innovation among smallholders in Bangladesh for reducing hunger and improving food security. BRAC applies a mix of multiple approaches, ranging from better adapted and higher yielding crop varieties to improved production processes to agricultural microcredit schemes. The combination of innovations and interventions which address what matters for communities and their involvement in the development process, as well as the provision of extension services, is an encouraging example of diversified agricultural development strategies, which are also being implemented in Africa.

Strong linkages between research and extension organizations in Ethiopia's agricultural innovation system are also the focus of the authors in Chap. 7. With reference to the Ethiopian Agriculture Development Partners Linkage Advisory Council (ADPLAC), their findings show how important it is to institutionalize joint research and extension processes by improving accountability, monitoring and evaluation. The involvement of stakeholders in the innovation process is also crucial.

Opportunities for innovations in the Ethiopian seed system are outlined by Husmann in Chap. 8. The study underlines the importance of transaction costs, as demonstrated by Iskandar and Gatzweiler in Chap. 5. The current government 
dominated seed system is characterized by transaction costs which make it less attractive for the private sector to invest and meet the demand for improved seeds. Although seed demand assessments are carried out at a local level and passed on to governmental agencies which eventually engage in seed production, the lack of a market price system and of agro-dealers make distribution of seeds inefficient. Governmental control prevents private seed companies from breeding and seed production. Prices are set after a negotiation process between governmental organizations and not based on a farmer's actual willingness to pay. Further, the transaction costs involved in the seed system are carried by the government and not covered by the price of the seed, which is a disincentive to engage in efficient seed provision. Institutional innovations are proposed to improve access to and supply of seeds in Ethiopia.

Mobile communication technology plays an important role in the set of diversification strategies for innovation in agriculture. In Chap. 9, Baumüller investigates the effect of delivering services through mobile phones to smallholders in Kenya by outlining the key factors that have supported the growth of the Kenyan $\mathrm{m}$-services sector. From her case study, the author concludes that, as a result of accessing information on demand and price, some farmers have changed their cropping patterns, whereas it remains inconclusive whether their bargaining power improved as a result of improved access to price information. The author recommends $\mathrm{m}$-services to be embedded in complementary support programs and infrastructure developments to tackle other production and marketing limitations smallholders are facing. The author's findings support an essential argument throughout this volume: in order to improve the quality of life of smallholders in Sub-Saharan Africa and South Asia, technological innovations need to be accompanied by innovations in the broader institutional infrastructure.

In Chap. 10, Wünscher and Tambo present an innovative approach for identifying farmer innovations in upper East Ghana. By means of a farmer innovation contest, innovation behavior of farmers is stimulated. They become more creative, share their knowledge and engage in experimentation. The authors point to the fact that, despite poverty, a farmer's innovative capacity remains part of their capabilities, which can be made use of by changing incentive systems for innovation. Before introducing innovations, this human resource of creativity and innovation can be made better use of, reducing a farmer's dependence on external inputs (Gatzweiler, Chap. 2) and strengthening identity and self-esteem (Kumar, Chap. 4).

The contribution of women in agriculture tends to be undervalued, and innovations affect or bypass women in different ways. In Chap. 11, Beuchelt looks at gender and social equity trade-offs related to the promotion and diffusion of improved technologies for agricultural development. Her analysis underlines the importance of the social context-specificity of innovations in agriculture and calls for ex-ante assessments of potential gender and social effects from the introduction of innovations. Introducing innovations in a more participatory and gender sensitive manner can significantly contribute to meeting the food and nutritional needs of marginalized smallholders. 
Productivity in agriculture does not only need to increase, it also needs to be sustainable. Adoption of new technologies depends on whether they are adapted to local conditions. In Chap. 12, Kriesemer, Virchow and Weinberger present an approach for assessing the sustainability and suitability of agricultural innovations for rural smallholders, taking into consideration environmental resilience, economic viability, and social sustainability, as well as technical sustainability. They develop indicators which help smallholders and local extension agents to make decisions which are locally adapted and more sustainable, increasing resilience.

Innovative sustainable land management (SLM) technologies and practices can help in addressing land degradation and improving rural livelihoods, however, they are not generally being adopted at larger scales. Mirzabaev (Chap. 13) looks at factors constraining the adoption of SLM innovations and identifies the major incentives for adoption: access to markets, credit and extension, as well as secure land tenure. SLM technologies alone, however, cannot comprehensively address land degradation. From his review, Mirzabaev concludes that a combination of technological, social and economic changes, achieved through synergies of bottom-up and top-down approaches, has led to successful examples for sustainable land management.

Virchow, Beuchelt, Kuhn and Denich (Chap. 14) look at the potentials of biomass-based value webs for economies in Sub-Saharan Africa by merging value chains into value webs. They apply a multi-dimensional methodology to understand the inter-linkages of value chains as a system of flexible, efficient and sustainable production, processing, trading and consumption, which they have termed "value webs". Their systems approach focuses on alternative uses of raw products, including recycling processes and cascading effects, during the processing phase of biomass utilization. This innovative perspective goes beyond the controversy of food versus non-food cropping systems, and helps identify synergy effects by combining the food and non-food branch of the biomass-based bioeconomy. These can lead to improved food security, employment, urgently needed export earnings, and to the conservation of environmental assets.

Part III presents contributions which show pathways towards sustainable intensification by the adoption of stress tolerant rice varieties, access to and use of improved seeds, and by adjusted crop combinations, such as integrated rice-fish farming practices, growing vegetables, cocoa, ginger and maize in Ghana, or wheat, rice and pulses for the Indian states of Odisha and Bihar. The contributions show where, how and under which circumstances further productivity growth potentials can be made use of by sustainable intensification strategies in agriculture.

In Chap. 15, Ahmed, Hernandez and Naher evaluate the adoption, retention, and diffusion of a set of modern stress-tolerant rice varieties promoted by the Cereal Systems Initiative in Bangladesh. Cultivating stress tolerant rice varieties is especially relevant in Bangladesh, which is one of the countries suffering the worst effects of climate change. The authors found generally higher adoption rates among educated and medium to large farmers but a relatively low adoption of stresstolerant varieties by marginal farmers, which could be explained by their high risk aversion. The coverage of area under stress-tolerant varieties was found to be very low. High-yielding rice varieties which were introduced three decades ago are now 
being replaced by varieties which perform better under stressful agro-ecological conditions such as soil salinity, drought or submergence.

In Chap. 16, Malek, Hoque, Yesmin and Haque conducted a household survey in 5855 marginalized households and ask whether only cereal based cropping technologies can improve food and livelihood security of poor smallholders in marginal areas of Bangladesh. The authors carry out a mapping exercise for the identification of marginal rural areas with potential and then carry out an in-depth household analysis. The authors identify unused potential in each district and conclude that adverse agro-ecological conditions and associated perceived risks discourage poor smallholders from taking innovative steps and adopting technology useful for agricultural intensification. Cereal-based technologies are recommended as part of the solution, but should be integrated with other income diversification and agricultural diversification strategies. Intensive crop system, hybrid seeds, water management technologies, non-crop farming, non-farm enterprise and business are the suggested potential technological innovations for the study areas.

In Chap. 17, Islam carries out value chain, partial budgeting and SWOT analysis for assessing competitive performance and identifying the key factors affecting adoption and diffusion of rice-fish technology by indigenous farmers in Bangladesh. The overall quantitative results from gross margin, partial budgeting and gendered employment analysis show positive benefits due to the introduction of rice-fish technology as compared to rice monoculture. Findings indicate that ricefish systems offer considerable potential for increasing overall agricultural productivity and farm incomes. Those potentials could be realized by government support and better value chain development.

The potentials of technologies for maize, wheat, rice and pulses in marginal areas of Bihar and Odisha, India are assessed in Chap. 18 by Joshi, Roy, Sonkar and Tripathi. Through multi-stakeholder consultations and secondary data analysis, the authors assess the potential of those technologies in terms of their agro-ecological suitability, as well as required complementary inputs. Maize and pulses are identified as crops that farmers aspire to cultivate. Their analysis also reveals that, in both states, there is a general, significant lack of awareness about agricultural technology. There is also a dissonance between expert technology evaluations and the valuations of likely adopters. Hybrid rice and varietal improvements in wheat and organic/semi organic farming are among the technologies with potential in the study area. Adoption of technologies which require more complementary inputs has been more difficult. The authors call for a holistic approach, taking the entire process from information to adoption support into account.

Chapter 19 presents an assessment of technological innovations for marginalized smallholders in Ghana. The authors explore community-based technologies that have the greatest potential for reducing poverty and vulnerability. Their findings show that the dominant technologies with the potential to reduce smallholder farmers' poverty in specific areas are inorganic fertilizers for Afigya-Kwabre; zero tillage for AmansieWest; storage facilities for Atebubu-Amantin; marketing facilities for Kintampo South; improved varieties for Gonja East; and pesticides for the Tolon Districts. 
This study also underlines the importance of complementary government interventions and strengthening of extension services for marginalized farmers.

Hundie and Admassie (Chap. 20) assess the potential impact of yield increasing crop technologies on productivity and poverty based on data collected from two districts of Ethiopia: Basoliben in the Amhara region and Halaba in the Southern Nations, Nationalities and Peoples' region. The use of improved seeds, chemical fertilizer use and rowplanting techniques are considered to be promising technologies. The authors used the partial budget approach to analyze the potential impacts of those technologies. Results show that the mean per capita net benefit per day from technology adoption would be enough to lift the "better-off-poor" households out of poverty; not so, however, for the ultra-poor who require other livelihood strategies for improving their wellbeing.

\section{Conclusions and Implications for Policy and Research}

Sustainable intensification in agriculture is a response to the locally and globally increasing demand for food and non-food agricultural products, the need to maintain the functions of ecosystems and the stagnating availability of productive land. The contributions to this volume have reconfirmed that sustainable intensification is not just another optimization problem for ensuring higher productivity with less environmental impact. Rather it is a complex task of creating value through innovations in the institutional, organizational and technological systems of societies. Sustainable intensification is therefore not only a challenge to be met by and within the agricultural sector alone, but by society at large.

Opportunities for creating value by means of institutional, organizational and technological innovations can be grasped in two broad dimensions: in the dimension of human capabilities and that of agro-ecological potential. Whereas technological innovations help to close yield gaps, improve efficiency of production, and make full use of agro-ecological potentials, institutional and organizational innovations create the societal environment which enables people to make full use of their capabilities.

Depending on the specific context in which innovations are sought, strategies towards sustainable intensification will need to be more people and/or area-focused. These strategies include:

1. Intensifying crop production and minimizing environmental impact by making use of improved varieties and technologies adjusted to changing environmental and climatic conditions.

2. Diversifying agricultural crop production and production techniques to reduce external inputs and risks of failure and maintain agro-biodiversity.

3. Diversifying income opportunities and facilitating exit strategies, as well as enabling private business opportunities. 
4. Providing basic educational, food, and health services for the most deprived, including them in social safety nets, and connecting them to communication and transport infrastructure.

Common lessons from the contributions to this volume confirm those conclusions and underline the importance of strategies which involve technological and institutional innovations. They can be summarized as follows:

1. Innovations for sustainable intensification in agriculture can be created in multiple value domains of society. Improving the wellbeing of smallholders means facilitating a change to positions in social and economic systems in which they are less marginalized. Being inclusive and sensitive to gender and social inequalities is not just fairer but also contributes to improving productivity.

2. Creating linkages and incentives which facilitate learning and encourage exchange of knowledge about innovations in agriculture. Such linkages unleash productivity potentials in the creation of value chains and value webs, stimulate private business engagement and improve collaboration between research and extension organizations. Apart from the pivotal role of smallholders themselves, entrepreneurs and governments need to collaborate to achieve sustainable intensification.

3. Technological innovations in various domains, such as mobile phones, stress-tolerant, high-yielding varieties and quality seeds, sustainable land management technologies and integrated farming, need to come together, rather than being pursued in isolation. They have the potential to boost productivity of smallholders. Actual productivity increases, however, depend on the extent of adoption. Adoption among poor smallholders tends to improve with increasing levels of education, increasing farm size and decreasing risk aversion.

4. Maintaining the sustainability of agricultural technologies for productivity growth requires a two-tiered dynamic approach: making technologies peopleready and making people technology-ready. Adjusting introduced technologies to the local context and local capabilities is as important as improving education and skills.

By investing more in farms, and by increasing efficiency of farming, a large portion of poverty and malnutrition could be reduced. Small farms play multifunctional roles in development (HLPE 2013). Importantly, public policies need to regard small farms as a part of a broader development solution. Policy support should be aimed at promoting the dynamism within the family farm sector itself, but also enhancing the dynamic interactions and integration of the family farm sector into the rest of the economy. All three options for small farm transformation need public policy attention, not just a smallholder growth strategy.

Small farmers can play key roles in fostering rural growth. It can no longer be assumed that the millions of small farmers will remain a peacefully suffering community in the future. Information and access to political influence through elections, farmer organizations, and more decentralized political systems are changing the context. Governments need to recognize and uphold smallholder 
rights, including the right to food, the right for self-organization, and the right to land and gaining equitable access to common pool natural resources (HLPE 2013). Crucially, these rights should be equally enjoyed by both men and women. There will be multiple futures for small farms. Appropriate policies facilitating the improvements of marginalized small farm communities need to be adjusted to the specific local and country contexts. Innovations play a key role in this.

Open Access This chapter is distributed under the terms of the Creative Commons AttributionNoncommercial 2.5 License (http://creativecommons.org/licenses/by-nc/2.5/) which permits any noncommercial use, distribution, and reproduction in any medium, provided the original author(s) and source are credited.

The images or other third party material in this chapter are included in the work's Creative Commons license, unless indicated otherwise in the credit line; if such material is not included in the work's Creative Commons license and the respective action is not permitted by statutory regulation, users will need to obtain permission from the license holder to duplicate, adapt or reproduce the material.

\section{References}

Beddow JA, Parday PG, Koo J, Wood S (2010) The changing landscape of global agriculture. In: Alston J, Babcock B, Pardey P (eds) The shifting patterns of agricultural production and productivity worldwide. Iowa State University, The Midwest Agribusiness Trade Research and Information Center (MATRIC), Ames

Bergek A, Jacobsson S, Hekkert M, Smith K (2010) Functionality of innovation systems as a rationale for and guide to innovation policy. In: Smits RE, Kuhlmann S, Shapira P (eds) The theory and practice of innovation policy: an international research handbook. Edward Elgar, Cheltenham/Northampton, pp 115-144

Berry RA, Cline WR (1979) Agrarian structure and productivity in developing countries. John Hopkins University Press, Baltimore/London

Binswanger HP, Rosenzweig MR (1986) Behavioural and material determinants of production relations in agriculture. J Dev Stud 22(3):503-539

Chavas JP (2001) Structural change in agricultural production: economics, technology and policy. In: Gardner BL, Rausser GC (eds) Handbook of agricultural economics, vol 1, Part 1. Elsevier, Amsterdam/London, pp 263-285

Conway G, Waage J (2010) Science and innovation for development. UK Collaborative on Development Sciences (UKCDS), London

Eastwood R, Lipton M, Newell A (2010) Farm size. In: Pingali PL, Evenson RE (eds) Handbook of agricultural economics, vol 4, Elsevier. Amsterdam, London, pp 3323-3397

Fan S, Chan-Kang C (2005) Is small beautiful? Farm size, productivity, and poverty in Asian agriculture. Agric Econ 32(s1):135-146

FAO (2010) Characterisation of small farmers in Asia and the Pacific. Asia and Pacific Commission on agricultural statistics, twenty-third session, Siem Reap, 26-30 Apr 2010

Farrington J, Holmes R, Slater R (2007) Linking social protection and the productive sectors, ODI briefing paper 28. Overseas Development Institute, London

Fuglie K, Nin-Pratt A (2013) Agricultural productivity: a changing global harvest. 2012 Global food policy report. International Food Policy Research Institute, Washington DC, pp 15-28

Hayami Y (1996) The peasant in economic modernization. Am J Agric Econ 78(5):1157-1167

Hazell P, Poulton C, Wiggins S, Dorward A (2010) The future of small farms: trajectories and policy priorities. World Dev 38(10):1349-1361 
Heltberg R (1998) Rural market imperfections and the farm size-productivity relationship: evidence from Pakistan. World Dev 26(10):1807-1826

Hirway I, Shah N (2011) Labour and employment under globalisation: the case of Gujarat. Econ Polit Weekly 46(22):57-65

HLPE (2013) Investing in smallholder agriculture for food security. A report by the high level panel of experts on food security and nutrition of the committee on world food security, Rome

Holmes R, Jones N (2009) Gender inequality, risk and vulnerability in the rural economy: refocusing the public works agenda to take account of economic and social risks, background report for the state of food and agriculture 2010. Overseas Development Institute, London

IFPRI (2009) India state hunger index, in report on global hunger index. International Food Policy Research Institute, Washington, DC

ILO (2006) Tackling hazardous child labour in agriculture: guidance on policy and practice. International programme on the elimination of child labour. International Labour Organisation, Geneva

Juma C, Tabo R, Wilson K, Conway G (2013) Innovation for sustainable intensification in Africa, the Montpellier panel. Agriculture for Impact, London

Le QB, Nkonya E, Mirzabaev A (2014) Biomass productivity-based mapping of global land degradation hotspots, ZEF discussion papers 193. Center for Development Research, Bonn

Leeuwis C, Ban A (2004) Communication for rural innovation: rethinking agricultural extension. Oxford Blackwell Science, Oxford

Llewelyn RV, Williams JR (1996) Nonparametric analysis of technical, pure technical, and scale efficiencies for food crop production in East Java, Indonesia. Agric Econ 15(2):113-126

Lowder SK, Skoet J, Singh S (2014) What do we really know about the number and distribution of farms and family farms in the world? Background paper for the state of food and agriculture 2014. Food and Agriculture Organization of the United Nations, Rome

Nkonya E, Gerber N, Baumgartner P, von Braun J, De Pinto A, Graw V, Kato E, Kloos J, Walter T (2011) The economics of desertification, land degradation, and drought: toward an integrated global assessment, ZEF discussion papers on development policy No 150. Center for Development Research, Bonn

Olinto P, Beegle K, Sobrado C, Uematsu H (2013) The state of the poor: where are the poor, where is extreme poverty harder to end, and what is the current profile of the world's poor? World Bank, Washington, DC

Pingali P (2012) Green revolution: impacts, limits and the path ahead. Proc Natl Acad Sci U S A 109:12302-12308

Schultz TW (1964) Transforming traditional agriculture. Yale University Press, New Haven

Sen A (1999) Development as freedom. Harvard University Press, Cambridge

Shukla R (2010) The official poor in India summed up. IJHD 4(2):301-328

Singh S (2012) The woes of rural wage labour. The limitations of inclusiveness. Institute of Economic Growth, New Delhi

Singh I, Squire L, Strauss J (1986) Agricultural household models: extensions, applications, and policy. Johns Hopkins University Press, Baltimore

The Montpellier Panel (2013) Sustainable intensification: a new paradigm for African agriculture. Agriculture for Impact, London

Tschajanov AV (1923) Die Lehre von der bäuerlichen Wirtschaft: Versuch einer Theorie der Familienwirtschaft im Landbau. P. Parey, Madison

von Braun J (2005) Agricultural economics and distributional effects. Agric Econ 32(s1):1-20. doi:10.1111/j.0169-5150.2004.00011.x

von Braun J (2011) Food security and the futures of farms. In: Lindquist AK, Verba T (eds) Report from the Bertebos conference on "Food security and the futures of farms: 2020 and towards 2050", Falkenberg, 29-31 Aug 2010

von Braun J, Mirzabaev A (2015) Small farms: changing structures and roles in economic development. ZEF discussion paper, No. 204. Center for Development Research (ZEF), Bonn von Braun J, Gatzweiler FW (2014) Marginality. Addressing the nexus of poverty, exclusion and ecology. Springer, Dordrecht/Heidelberg/New York/London 
von Braun J, Kennedy E (eds) (1994) Agricultural commercialization, economic development, and nutrition. The Johns Hopkins University Press, Baltimore/London

Wiggins S, Kirsten J, Llambí L (2010) The future of small farms. Worl Dev 38(10):1341-1348

World Bank (2003) Reaching the rural poor: a renewed strategy for rural development. World Bank, Washington, DC

Yotopoulos PA, Lau LJ (1973) A test for relative economic efficiency: some further results. Am Econ Rev 63(1):214-223. doi:10.2307/1803137 